\title{
Actinocatenispora thailandica gen. nov., sp. nov., a new member of the family Micromonosporaceae
}

Correspondence
Somboon Tanasupawat
Somboon.T@Chula.ac.th

\author{
Chitti Thawai, ${ }^{1}$ Somboon Tanasupawat, ${ }^{2}{\text { Takashi } \text { Itoh }^{3} \text { and Takuji Kudo }}^{3}$
'Department of Applied Biology, Faculty of Science, King Mongkut's Institute of Technology, Ladkrabang, Bangkok 10520, Thailand Bangkok 10330, Thailand Japan \\ ${ }^{2}$ Department of Microbiology, Faculty of Pharmaceutical Sciences, Chulalongkorn University, \\ ${ }^{3}$ Japan Collection of Microorganisms, RIKEN BioResource Center, Wako, Saitama 351-0198,
}

Two actinomycete strains, TT2-10' and TT2-3, which produced long spore chains (more than 10 spores per chain), were isolated from peat swamp forest soil in Pattaloong Province, Thailand. Their taxonomic positions were determined using a polyphasic approach. The chemotaxonomic characteristics of these strains coincided with those of the family Micromonosporaceae, i.e. cell-wall chemotype II, muramic acid of the $N$-glycolyl type, whole-cell sugar pattern D and type II phospholipids. Analysis of the 16S rRNA gene sequences also indicated that these strains constitute a distinct lineage within the family Micromonosporaceae, sharing $91 \cdot 3-93 \cdot 8 \%$ sequence similarity with members of this family. On the basis of their phenotypic and genotypic characteristics and their phylogenetic position, these strains represent a novel genus and species, for which the name Actinocatenispora thailandica gen. nov., sp. nov. is proposed. The type strain of Actinocatenispora thailandica is strain TT2-10 $\left(=\mathrm{JCM} 12343^{\top}=\mathrm{PCU} 235^{\top}=\mathrm{DSM} 44816^{\top}\right)$.
The family Micromonosporaceae was first described by Krasil'nikov (1938), and its description has been emended by Koch et al. (1996) and Stackebrandt et al. (1997), who classified seven genera (Micromonospora, Actinoplanes, Dactylosporangium, Catellatospora, Catenuloplanes, Couchioplanes and Pilimelia) within it. Subsequently, the genera Spirilliplanes, Verrucosispora, Virgisporangium, Asanoa, Longispora and Salinispora have been recognized as novel genera of the family Micromonosporaceae on the basis of their chemotaxonomic characteristics and their phylogenetic positions, inferred from 16S rRNA gene sequences and signature nucleotides of this gene (Koch et al., 1996; Stackebrandt et al., 1997). During an investigation of the actinomycete diversity of soils in southern Thailand, we isolated two strains, TT2 $-10^{\mathrm{T}}$ and TT2-3, which showed chemotaxonomic characteristics typical of members of the family Micromonosporaceae but which represent a novel phylogenetic lineage. In this report, we describe the polyphasic characterization of these strains and propose their classification in a novel genus and species.

Strains TT2- $10^{\mathrm{T}}$ and TT2-3 were isolated from peat swamp forest soil in Pattaloong Province, Thailand. Samples were

The GenBank/EMBL/DDBJ accession numbers for the $16 \mathrm{~S}$ rRNA gene sequences of strains TT2-10 ${ }^{\top}$ and TT2-3 are AB107233 and AB159211, respectively. taken from the soil surface and were kept at $4{ }^{\circ} \mathrm{C}$. The sampling and isolation methods were as described by Thawai et al. (2004), and the pure culture was kept at $4-10{ }^{\circ} \mathrm{C}$ on yeast extract-malt extract agar (ISP 2 medium) slants.

Strains TT2-10 ${ }^{\mathrm{T}}$ and TT2-3 were grown for 14 days at $30{ }^{\circ} \mathrm{C}$ on oatmeal-nitrate agar and observed by using light microscopy and scanning electron microscopy (model JSM-5410 LV; JEOL). Samples for scanning electron microscopy were prepared as described previously (Itoh et al., 1989).

Cultural, physiological and biochemical characteristics were examined by using several standard methods; cultural characteristics were tested using 14 day cultures grown at $30{ }^{\circ} \mathrm{C}$ on various agar media. Jacal Colour Card L2200 (Japan Colour Research Institute) was used for determining colour designations and names. The decomposition of various compounds was examined using the basal medium recommended by Gordon et al. (1974). Temperature, $\mathrm{NaCl}$ and $\mathrm{pH}$ tolerances were determined on ISP 2 medium. The utilization of various carbon sources was tested using ISP 9 medium (Shirling \& Gottlieb, 1966) supplemented with $1 \%$ (final concentration) carbon source and 0.05\% Casamino acids. Gelatin liquefaction, peptonization of milk, nitrate reduction, cellulose decomposition and starch hydrolysis were determined through cultivation on various media, as described by Arai (1975) and Williams \& Cross (1971). Melanin and hydrogen sulphide production were examined 
on tyrosine agar and peptone-iron agar slants supplemented with $0 \cdot 1 \%(\mathrm{w} / \mathrm{v})$ yeast extract.

Freeze-dried cells used for chemotaxonomic analyses were obtained from cultures grown in yeast extract-malt extract broth (ISP 2 broth) on a rotary shaker at $30^{\circ} \mathrm{C}$. Cell-wall peptidoglycan was prepared and hydrolysed according to the methods of Kawamoto et al. (1981), and the amino acid composition was determined with an automatic amino acid analyser. The isomers of diaminopimelic acid in the cell walls were determined by using the method of Staneck \& Roberts (1974). The acyl group of the muramic acid in the peptidoglycan was determined by using the method of Uchida \& Aida (1984). The reducing sugars from whole-cell hydrolysates were analysed by using the HPLC method of Mikami \& Ishida (1983). The phospholipids in the cells were extracted and analysed by using the method of Minnikin et al. (1984). Fatty acid methyl ester analysis was performed by means of GLC according to the instructions of the Microbial Identification System (MIDI) (Sasser, 1990; Kämpfer \& Kroppenstedt, 1996). Isoprenoid quinones were extracted by using the method of Collins et al. (1977) and were analysed by using HPLC [Cosmosil $5 \mathrm{C}_{18}$ column $(4 \cdot 6 \times 150 \mathrm{~mm})$; Nacalai Tesque]. The elution solvent was a mixture of methanol and 2-propanol $(2: 1, \mathrm{v} / \mathrm{v})$.

Chromosomal DNA was isolated from cells grown in ISP 2 broth according to the method of Tamaoka (1994). The $\mathrm{G}+\mathrm{C}$ content of the DNA was determined using the HPLC method of Tamaoka \& Komagata (1984). An equimolar mixture of nucleotides for analysis of the DNA G + C content (Yamasa Shoyu) was digested by bacterial alkaline phosphatase into nucleosides and used as the quantitative standard. DNA-DNA relatedness was measured fluorometrically using the microplate hybridization method devised by Ezaki et al. (1989). Hybridization was carried out at $55^{\circ} \mathrm{C}$ for $2 \mathrm{~h}$.

Genomic DNA extraction, PCR-mediated amplification of the 16S rRNA gene and sequencing of the PCR products were carried out as described by Nakajima et al. (1999). The $16 \mathrm{~S}$ rRNA gene sequence was multiply aligned with selected sequences from the GenBank/EMBL/DDBJ databases using CLUSTAL W, version 1.81 (Thompson et al., 1994). Alignments were verified manually and adjusted prior to the construction of a phylogenetic tree. The phylogenetic tree was constructed using the neighbour-joining (Saitou \& Nei, 1987) and maximum-parsimony methods (Kluge \& Farris, 1969) in MEGA, version 2.1. Confidence values for the branches of the phylogenetic tree were determined using bootstrap analyses (Felsenstein, 1985) based on 1000 resamplings. 16S rRNA gene sequence similarities among closely related genera were calculated manually after pairwise alignments had been obtained using CLUSTAL $\mathrm{X}$ (Thompson et al., 1997). Gaps and ambiguous nucleotides were eliminated from the calculations.

Strains TT2-10 ${ }^{\mathrm{T}}$ and TT2-3 produced well-developed substrate mycelia on ISP 2 agar, oatmeal agar (ISP 3), inorganic salts-starch agar (ISP 4), peptone-yeast extract-iron agar (ISP 6), tyrosine agar (ISP 7) and glucose-asparagine agar. Aerial mycelia and spores were absent on these media, but white aerial mycelia were formed with cultivation on oatmeal-nitrate agar. Spore chains were borne on the aerial mycelia and each consisted of more than 10 spores (Fig. 1). The spore surface appeared to be smooth. Spores were cylindrical, approximately $0 \cdot 3-0 \cdot 4 \times 0 \cdot 5-1 \cdot 0 \mu \mathrm{m}$ in size and non-motile. The colonies of strains TT2- $10^{\mathrm{T}}$ and TT2-3 were yellow to vivid yellow-orange in colour; soluble pigments were not produced on most of the media tested, with the exception of a yellow pigment on oatmeal agar. The physiological and biochemical characteristics of the strains are presented in the species description.

Cell-wall hydrolysates of the two strains contained glutamic acid, glycine, alanine and meso-diaminopimelic acid, indicating that these strains have wall chemotype II (described by Lechevalier \& Lechevalier, 1970); the peptidoglycan was of type A1 $\gamma$ (described by Schleifer \& Kandler, 1972). The acyl type of the cell-wall muramic acid was glycolyl. The strains contained glucose, galactose, xylose, arabinose, mannose and ribose as whole-cell sugars, but rhamnose was not detected. This result suggests that the whole-cell sugar profile was pattern D of Lechevalier \& Lechevalier (1970). The characteristic phospholipids were diphosphatidylglycerol, phosphatidylinositol, phosphatidylinositol mannosides, phosphatidylethanolamine and unidentified ninhydrin-negative phospholipids, but phosphatidylcholine was not present. This pattern corresponds to phospholipid type II of Lechevalier et al. (1977). The cellular fatty acid compositions are shown in Table 1. The major fatty acids of strains TT2- $10^{\mathrm{T}}$ and TT2-3 were iso- $\mathrm{C}_{16: 0}$, anteiso- $\mathrm{C}_{17: 0}$, iso- $\mathrm{C}_{15: 0}$ and iso- $\mathrm{C}_{17: 0}$. This pattern corresponds to fatty acid type 3 b of Kroppenstedt (1985). Mycolic acids were absent. The predominant menaquinones were MK-9 $\left(\mathrm{H}_{4}\right)$ and MK-9 $\left(\mathrm{H}_{6}\right)$ and small amounts of MK-9 $\left(\mathrm{H}_{2}\right)$ and MK- $9\left(\mathrm{H}_{8}\right)$ were also present. The DNA G $+\mathrm{C}$ contents for strains TT2- $10^{\mathrm{T}}$ and TT2-3 were $72 \cdot 2$ and $72 \cdot 3 \mathrm{~mol} \%$, respectively.

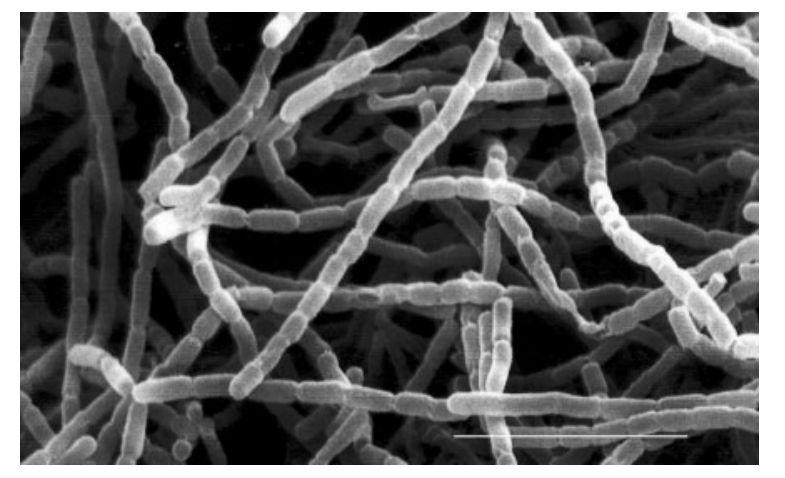

Fig. 1. Scanning electron micrograph of strain TT2-10 ${ }^{\top}$. Bar, $5 \mu \mathrm{m}$. 
Table 1. Cellular fatty acid composition of strains TT2-10 and TT2-3

Values are percentages of total fatty acids. -, Not detected.

\begin{tabular}{|c|c|c|}
\hline Fatty acid & Strain TT2-10 ${ }^{\mathrm{T}}$ & Strain TT2-3 \\
\hline \multicolumn{3}{|l|}{ Saturated fatty acids } \\
\hline $\mathrm{C}_{12: 0}$ & $0 \cdot 2$ & - \\
\hline $\mathrm{C}_{13: 0}$ & $0 \cdot 1$ & $0 \cdot 1$ \\
\hline $\mathrm{C}_{14: 0}$ & $0 \cdot 1$ & $0 \cdot 1$ \\
\hline $\mathrm{C}_{14: 0} 2-\mathrm{OH}$ & $1 \cdot 6$ & $0 \cdot 6$ \\
\hline $\mathrm{C}_{15: 0}$ & $0 \cdot 3$ & $0 \cdot 4$ \\
\hline $\mathrm{C}_{16: 0}$ & $0 \cdot 3$ & $0 \cdot 3$ \\
\hline $\mathrm{C}_{17: 0}$ & $0 \cdot 7$ & $0 \cdot 5$ \\
\hline $\mathrm{C}_{18: 0}$ & - & $0 \cdot 1$ \\
\hline $\mathrm{C}_{19: 0}$ & $0 \cdot 2$ & $0 \cdot 2$ \\
\hline \multicolumn{3}{|l|}{ Unsaturated fatty acids } \\
\hline $\mathrm{C}_{16: 1} \omega 11 c$ & $0 \cdot 1$ & $0 \cdot 2$ \\
\hline $\mathrm{C}_{17: 1} \omega 5 c$ & $0 \cdot 7$ & $0 \cdot 5$ \\
\hline $\mathrm{C}_{18: 1} \omega 7 c$ & $1 \cdot 8$ & $2 \cdot 2$ \\
\hline $\mathrm{C}_{18: 3} \omega 6 c(6,9,12)$ & $1 \cdot 2$ & $1 \cdot 5$ \\
\hline \multicolumn{3}{|l|}{ Branched fatty acids } \\
\hline $\mathrm{i}-\mathrm{C}_{13: 0}$ & $0 \cdot 2$ & $0 \cdot 1$ \\
\hline ai- $C_{13: 0}$ & $0 \cdot 1$ & - \\
\hline $\mathrm{i}-\mathrm{C}_{13: 0} 3-\mathrm{OH}$ & $0 \cdot 1$ & - \\
\hline $\mathrm{i}-\mathrm{C}_{14: 0}$ & $2 \cdot 6$ & $1 \cdot 9$ \\
\hline $\mathrm{i}-\mathrm{C}_{14: 0} 3-\mathrm{OH}$ & $3 \cdot 9$ & $2 \cdot 2$ \\
\hline $\mathrm{i}-\mathrm{C}_{15: 0}$ & $20 \cdot 2$ & $19 \cdot 2$ \\
\hline ai- $\mathrm{C}_{15: 0}$ & $6 \cdot 0$ & $6 \cdot 2$ \\
\hline $\mathrm{i}-\mathrm{C}_{16: 0}$ & $26 \cdot 2$ & $21 \cdot 3$ \\
\hline $\mathrm{i}-\mathrm{C}_{16: 1}$ & $0 \cdot 9$ & $0 \cdot 9$ \\
\hline $\mathrm{i}-\mathrm{C}_{17: 0}$ & $11 \cdot 3$ & $13 \cdot 9$ \\
\hline ai- $C_{17: 0}$ & $19 \cdot 3$ & $25 \cdot 9$ \\
\hline ai- $C_{17: 1}$ & $0 \cdot 6$ & $0 \cdot 6$ \\
\hline $\mathrm{i}-\mathrm{C}_{18: 0}$ & $0 \cdot 2$ & $0 \cdot 2$ \\
\hline Summed feature $2 b^{\star}$ & $0 \cdot 2$ & - \\
\hline
\end{tabular}

*Summed feature $2 \mathrm{~b}$ contains $\mathrm{C}_{16: 1}$ and/or $\mathrm{C}_{14: 0} 3-\mathrm{OH}$.

These chemotaxonomic characteristics, in particular the cell-wall type (type II), the muramic acid acyl type $(N$-glycolyl), the whole-cell sugar profile (pattern $\mathrm{D})$ and the phospholipid type (type II), suggested that strains TT2- $10^{\mathrm{T}}$ and TT2-3 were members of the family Micromonosporaceae. The family Micromonosporaceae currently accommodates 13 genera: Micromonospora Ørskov 1923, Actinoplanes Couch 1950, Pilimelia Kane 1966, Dactylosporangium Thiemann et al. 1967, Catellatospora Asano and Kawamoto 1986, Catenuloplanes Yokota et al. 1993, Couchioplanes Tamura et al. 1994, Spirilliplanes Tamura et al. 1997, Verrucosispora Rheims et al. 1998, Virgisporangium Tamura et al. 2001, Asanoa Lee and Hah 2002, Longispora Matsumoto et al. 2003 and Salinispora Maldonado et al. 2005. The morphological characteristics of strains TT2- $10^{\mathrm{T}}$ and TT2-3 were similar to those of members of the genera Longispora, Catellatospora, Catenuloplanes, Asanoa, Couchioplanes and Spirilliplanes in terms of spore-chain $\hat{\theta} \hat{\vec{A}} \dot{\vec{n}} \overrightarrow{0}$

\& 8

की

के ڤे

छิ

$\mathrm{\Xi}$

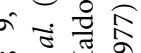

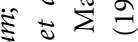

政

药

它

हैं वें

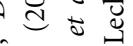

îे वे

要

荡 0 
production, but these genera (except Longispora) could be distinguished on the basis of spore motility and true aerial mycelium production. The genus Longispora seems to be the genus most closely related to strains TT2 $-10^{\mathrm{T}}$ and TT2-3, but the major menaquinones and fatty acid composition of its members distinguished them from strains TT2 $-10^{\mathrm{T}}$ and TT2-3. These results indicated that strains TT2 $-10^{\mathrm{T}}$ and TT2-3 do not belong to any known genera in the family Micromonosporaceae. Differential characteristics for the isolates and members of related genera in the family Micromonosporaceae are shown in Table 2.

Almost complete 16S rRNA gene sequences (1444 and $1434 \mathrm{nt}$ for strains TT2-10 $0^{\mathrm{T}}$ and TT2-3, respectively) were used for phylogenetic analysis with those of members of the order Actinomycetales. Phylogenetic analysis of this large dataset revealed that strains TT2- $10^{\mathrm{T}}$ and TT2-3 were positioned within the cluster of the family Micromonosporaceae (data not shown). When the sequences of strains TT2-10 ${ }^{\mathrm{T}}$ and TT2-3 were compared with corresponding sequences from all of the type species of recognized members of the family Micromonosporaceae and selected sequences from members of related families, they were found to form a distinct phylogenetic lineage within the family Micromonosporaceae and were also found to be separate from closely related families in the neighbour-joining analysis (with high levels of bootstrap support) (Fig. 2). 16S rRNA gene sequence similarities between strain TT2- $10^{\mathrm{T}}$ and members of the family Micromonosporaceae ranged from $91 \cdot 3 \%$ (with Longispora albida) to $93.8 \%$ (with Salinispora arenicola), and strain $\mathrm{TT} 2-10^{\mathrm{T}}$ showed $99 \cdot 7 \%$ sequence similarity to strain TT2-3; these similarities represent 127, 96 and 4 nucleotide differences, respectively. Additionally, strains TT2-10 ${ }^{\mathrm{T}}$ and TT2-3 had no more than $93 \%$ sequence similarity with members of any of the other families with which they were compared. Furthermore, the 16S rRNA gene sequences of strains TT2-10 ${ }^{\mathrm{T}}$ and TT2-3 contained the majority of the signature nucleotides of members of the family Micromonosporaceae (Stackebrandt et al., 1997), except for variations at some positions (position 502:543, U-G; position 747, G; and position 811, C; Escherichia coli numbering). On the basis of phenotypic and genotypic data, strains TT2-10 ${ }^{\mathrm{T}}$ and TT2-3 are readily distinguishable from the members of all established genera in the family Micromonosporaceae. Therefore, we propose that strains TT2- $10^{\mathrm{T}}$ and TT2-3 should be classified in a novel genus and species, for which the name Actinocatenispora thailandica gen. nov., sp. nov. is proposed.

\section{Description of Actinocatenispora gen. nov.}

Actinocatenispora [Ac.ti.no.ca.te.ni.spo' ra. Gr. n. actinos ray; L. n. catena chain; Gr. n. spora seed; N.L. fem. n. Actinocatenispora spore chain-producing ray (fungus)].

Gram-positive, non-acid-fast, non-motile and aerobic organisms with branching substrate hyphae. Aerial hyphae are formed and bear spore chains each consisting of more than 10 spores. Spores are cylindrical $(0.3-0 \cdot 4 \times 0.5-1.0 \mu \mathrm{m})$ and the spore surface is smooth. In general, substrate mycelia are yellow to vivid orange in colour. Cell wall contains glutamic acid, glycine, alanine and meso-diaminopimelic acid. The $\mathrm{N}$-acyl group of the cell-wall muramic acid is glycolyl. Galactose, xylose, arabinose, glucose, mannose and ribose are detected as whole-cell sugars. Contains phosphatidylethanolamine, diphosphatidylglycerol, phosphatidylinositol, phosphatidylinositol mannosides, phosphatidylglycerol and unidentified ninhydrin-negative phospholipids as cellular phospholipids (phospholipid pattern type II). Predominant menaquinones are MK$9\left(\mathrm{H}_{4}\right)$ and MK-9 $\left(\mathrm{H}_{6}\right)$; MK-9 $\left(\mathrm{H}_{2}\right)$ and MK- $9\left(\mathrm{H}_{8}\right)$ are minor components. Mycolic acids are not detected. The DNA $\mathrm{G}+\mathrm{C}$ content is $72 \mathrm{~mol} \%$. Habitat is soil. The type species is Actinocatenispora thailandica.

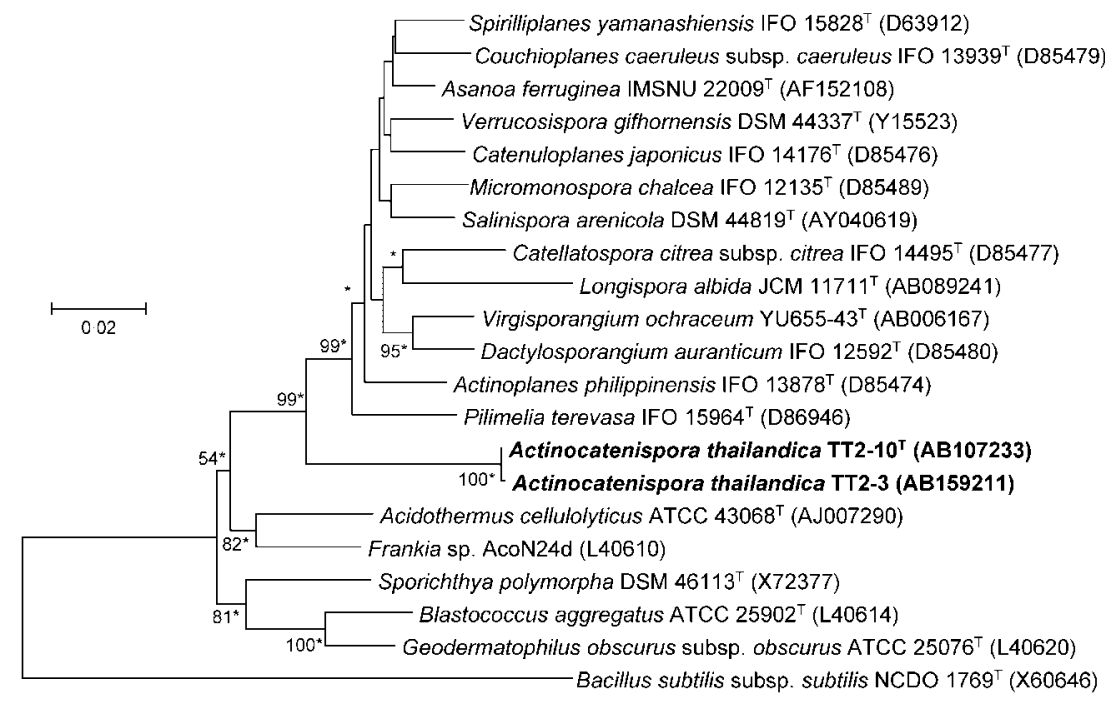

Fig. 2. Neighbour-joining tree (Saitou \& Nei, 1987), based on almost complete $16 \mathrm{~S}$ rRNA gene sequences, showing relationships among strains $T T 2-10^{\top}$ and TT2-3, all of the type species of recognized representative members of the family Micromonosporaceae and selected sequences of members of closely related families. The $16 \mathrm{~S}$ rRNA gene sequence of Bacillus subtilis subsp. subtilis NCDO $1769^{\top}$ was used as an outgroup. Asterisks indicate branches of the tree that were also found using the maximum-parsimony method (Kluge \& Farris, 1969). Numbers on branches indicate percentage bootstrap values from 1000 replicates; only values greater than $50 \%$ are indicated. Bar, 0.02 substitutions per nucleotide position. 


\section{Description of Actinocatenispora thailandica sp. nov.}

Actinocatenispora thailandica (thai.lan'di.ca. N.L. fem. adj. thailandica of Thailand, where the type strain was isolated).

The description of the morphological, chemotaxonomic and general characteristics are as described for the genus. White aerial mycelia are formed on oatmeal-nitrate agar. Soluble yellow pigment present on oatmeal agar. The type strain utilizes D-glucose, D-mannitol, D-melibiose, D-raffinose, glycerol, myo-inositol, salicin and cellobiose but not D-ribose, L-rhamnose, lactose, D-galactose, L-arabinose or D-fructose. Positive for reduction of nitrate, weakly positive for peptonization of milk and gelatin liquefaction and negative for hydrolysis of starch, formation of melanin and $\mathrm{H}_{2} \mathrm{~S}$ production. The optimal temperature for growth is $25-30^{\circ} \mathrm{C}$. No growth occurs above $40{ }^{\circ} \mathrm{C}$. Minimum pH tolerated is $4 \cdot 5$. Maximum $\mathrm{NaCl}$ concentration for growth is $7 \%$. The major cellular fatty acid components are iso$\mathrm{C}_{16: 0}$, anteiso- $\mathrm{C}_{17: 0}$, iso- $\mathrm{C}_{15: 0}$ and iso- $\mathrm{C}_{17: 0}$. The DNA $\mathrm{G}+\mathrm{C}$ content of the type strain is $72 \mathrm{~mol} \%$.

The type strain, TT2-10 $\left(=\mathrm{TCM} 12343^{\mathrm{T}}=\mathrm{PCU} 235^{\mathrm{T}}=\right.$ DSM $44816^{\mathrm{T}}$ ), was isolated from peat swamp forest soil in Pattaloong Province, Thailand.

\section{Acknowledgements}

The research grant from the Thailand Research Fund (to C.T.) is gratefully acknowledged. We thank M. Chijimatsu and H. Morishita (Research Resources Center, RIKEN Brain Science Institute, Wako, Japan) for analysing the amino acid composition of the cell-wall peptidoglycan.

\section{References}

Arai, T. (1975). Culture Media for Actinomycetes. Tokyo: The Society for Actinomycetes Japan (in Japanese).

Asano, K. \& Kawamoto, I. (1986). Catellatospora, a new genus of the Actinomycetales. Int J Syst Bacteriol 36, 512-517.

Collins, M. D., Pirouz, T., Goodfellow, M. \& Minnikin, D. E. (1977). Distribution of menaquinones in actinomycetes and corynebacteria. J Gen Microbiol 100, 221-230.

Couch, J. N. (1950). Actinoplanes. A new genus of the Actinomycetales. J Elisha Mitchell Sci Soc 66, 87-92.

Ezaki, T., Hashimoto, Y. \& Yabuuchi, E. (1989). Fluorometric deoxyribonucleic acid-deoxyribonucleic acid hybridization in microdilution wells as an alternative to membrane filter hybridization in which radioisotopes are used to determine genetic relatedness among bacterial strains. Int J Syst Bacteriol 39, 224-229.

Felsenstein, J. (1985). Confidence limits on phylogenies: an approach using the bootstrap. Evolution 39, 783-791.

Goodfellow, M., Stanton, L. J., Simpson, K. E. \& Minnikin, D. E. (1990). Numerical and chemical classification of Actinoplanes and some related actinomycetes. J Gen Microbiol 136, 19-36.

Gordon, R. E., Barnett, D. A., Handerhan, J. E. \& Pang, C. H.-N. (1974). Nocardia coeliaca, Nocardia autotrophica, and the nocardin strain. Int J Syst Bacteriol 24, 54-63.
Itoh, T., Kudo, T., Parenti, F. \& Seino, A. (1989). Amended description of the genus Kineosporia, based on chemotaxonomic and morphological studies. Int J Syst Bacteriol 39, 168-173.

Kämpfer, P. \& Kroppenstedt, R. M. (1996). Numerical analysis of fatty acid patterns of coryneform bacteria and related taxa. Can J Microbiol 42, 989-1005.

Kane, W. D. (1966). A new genus of Actinoplanaceae, Pilimelia, with a description of two species, Pilimelia terevasa and Pilimelia anulata. J Elisha Mitchell Sci Soc 82, 220-230.

Kawamoto, I., Oka, T. \& Nara, T. (1981). Cell wall composition of Micromonospora olivoasterospora, Micromonospora sagamiensis, and related organisms. J Bacteriol 146, 527-534.

Kluge, A. G. \& Farris, F. S. (1969). Quantitative phyletics and the evolution of anurans. Syst Zool 18, 1-32.

Koch, C., Kroppenstedt, R. M., Rainey, F. A. \& Stackebrandt, E. (1996). 16S ribosomal DNA analysis of the genera Micromonospora, Actinoplanes, Catellatospora, Catenuloplanes, Couchioplanes, Dactylosporangium, and Pilimelia and emendation of the family Micromonosporaceae. Int J Syst Bacteriol 46, 765-768.

Krasil'nikov, N. A. (1938). Ray Fungi and Related Organisms Actinomycetales. Moscow: Akademii Nauk SSSR (in Russian).

Kroppenstedt, R. M. (1985). Fatty acid and menaquinone analysis of actinomycetes and related organisms. In Chemical Methods in Bacterial Systematics, pp. 173-199. Edited by M. Goodfellow \& D. E. Minnikin. London: Academic Press.

Kudo, T., Nakajima, Y. \& Suzuki, K. (1999). Catenuloplanes crispus (Petrolini et al. 1993) comb. nov.: incorporation of the genus Planopolyspora Petrolini 1993 into the genus Catenuloplanes Yokota et al. 1993 with an amended description of the genus Catenuloplanes. Int J Syst Bacteriol 49, 1853-1860.

Lechevalier, M. P. \& Lechevalier, H. A. (1970). Chemical composition as a criterion in the classification of aerobic actinomycetes. Int J Syst Bacteriol 20, 435-443.

Lechevalier, M. P., De Bièvre, C. \& Lechevalier, H. A. (1977). Chemotaxonomy of aerobic actinomycetes: phospholipid composition. Biochem Syst Ecol 5, 249-260.

Lee, S. D. \& Hah, Y. C. (2002). Proposal to transfer Catellatospora ferruginea and 'Catellatospora ishikariense' to Asanoa gen. nov. as Asanoa ferruginea comb. nov. and Asanoa ishikariensis sp. nov., with emended description of the genus Catellatospora. Int J Syst Evol Microbiol 52, 967-972.

Lee, S. D., Kang, S. O. \& Hah, Y. C. (2000). Catellatospora koreensis sp. nov., a novel actinomycete isolated from a gold-mine cave. Int J Syst Evol Microbiol 50, 1103-1111.

Maldonado, L. A., Fenical, W., Jensen, P. R., Kauffman, C. A., Mincer, T. J., Ward, A. C., Bull, A. T. \& Goodfellow, M. (2005). Salinispora arenicola gen. nov., sp. nov. and Salinispora tropica sp. nov., obligate marine actinomycetes belonging to the family Micromonosporaceae. Int J Syst Evol Microbiol 55, 1759-1766.

Matsumoto, A., Takahashi, Y., Shinose, M., Seino, A., Iwai, Y. \& Omura, S. (2003). Longispora albida gen. nov., sp. nov., a novel genus of the family Micromonosporaceae. Int J Syst Evol Microbiol 53, 1553-1559.

Mikami, H. \& Ishida, Y. (1983). Post-column fluorometric detection of reducing sugar in high-performance liquid chromatography using arginine. Bunseki Kagaku 32, E207-E210.

Minnikin, D. E., O'Donnell, A. G., Goodfellow, M., Alderson, G., Athalye, M., Schaal, A. \& Parlett, J. H. (1984). An integrated procedure for the extraction of bacterial isoprenoid quinones and polar lipids. J Microbiol Methods 2, 233-241.

Nakajima, Y., Kitpreechavanich, V., Suzuki, K. \& Kudo, T. (1999). Microbispora corallina sp. nov., a new species of the genus Microbispora isolated from Thai soil. Int J Syst Bacteriol 49, 1761-1767. 
Ørskov, J. (1923). Investigations into the Morphology of the Ray Fungi. Copenhagen: Levin \& Munksgaard.

Rheims, H., Schumann, P., Rohde, M. \& Stackebrandt, E. (1998). Verrucosispora gifhornensis gen. nov., sp. nov., a new member of the actinobacterial family Micromonosporaceae. Int J Syst Bacteriol 48, 1119-1127.

Saitou, N. \& Nei, M. (1987). The neighbor-joining method: a new method for reconstructing phylogenetic trees. Mol Biol Evol 4, 406-425.

Sasser, M. (1990). Identification of bacteria by gas chromatography of cellular fatty acids. Technical Note 101. Newark, DE: MIDI, Inc.

Schleifer, K. H. \& Kandler, O. (1972). Peptidoglycan types of bacterial cell walls and their taxonomic implications. Bacteriol Rev 36, 407-477.

Shirling, E. B. \& Gottlieb, D. (1966). Methods for characterization of Streptomyces species. Int J Syst Bacteriol 16, 313-340.

Stackebrandt, E. \& Kroppenstedt, R. M. (1987). Union of the genera Actinoplanes Couch, Ampullariella Couch, and Amorphosporangium Couch in a redefined genus Actinoplanes. Syst Appl Microbiol 9, 110-114.

Stackebrandt, E., Rainey, F. A. \& Ward-Rainey, N. L. (1997). Proposal for a new hierarchic classification system, Actinobacteria classis nov. Int J Syst Bacteriol 47, 479-491.

Staneck, J. L. \& Roberts, G. D. (1974). Simplified approach to identification of aerobic actinomycetes by thin-layer chromatography. Appl Microbiol 28, 226-231.

Tamaoka, J. (1994). Determination of DNA base composition. In Chemical Methods in Prokaryotic Systematics, pp. 463-470. Edited by M. Goodfellow \& A. G. O’Donnell. Chichester: Wiley.

Tamaoka, J. \& Komagata, K. (1984). Determination of DNA base composition by reversed-phase high-performance liquid chromatography. FEMS Microbiol Lett 25, 125-128.

Tamura, T., Nakagaito, Y., Nishii, T., Hasegawa, T., Stackebrandt, E. \& Yokota, A. (1994). A new genus of the order Actinomycetales, Couchiplanes gen. nov., with descriptions of Couchioplanes caeruleus
(Horan and Brodsky 1986) comb. nov. and Couchioplanes caeruleus subsp. azureus subsp. nov. Int J Syst Bacteriol 44, 193-203.

Tamura, T., Hayakawa, M. \& Hatano, K. (1997). A new genus of the order Actinomycetales, Spirilliplanes gen. nov., with description of Spirilliplanes yamanashiensis sp. nov. Int J Syst Bacteriol 47, 97-102.

Tamura, T., Hayakawa, M. \& Hatano, K. (2001). A new genus of the order Actinomycetales, Virgosporangium gen. nov., with descriptions of Virgosporangium ochraceum sp. nov. and Virgosporangium aurantiacum sp. nov. Int J Syst Evol Microbiol 51, 1809-1816.

Thawai, C., Tanasupawat, S., Itoh, T., Suwanborirux, K. \& Kudo, T. (2004). Micromonospora aurantionigra sp. nov., isolated from a Thai peat swamp forest. Actinomycetologica 18, 8-14.

Thiemann, J. E., Pagani, H. \& Beretta, G. (1967). A new genus of the Actinoplanaceae: Dactylosporangium, gen. nov. Arch Mikrobiol 58, $42-52$.

Thompson, J. D., Higgins, D. G. \& Gibson, T. J. (1994). CLUSTAL W: improving the sensitivity of progressive multiple sequence alignment through sequence weighting, position-specific gap penalties and weight matrix choice. Nucleic Acids Res 22, 4673-4680.

Thompson, J. D., Gibson, T. J., Plewniak, F., Jeanmougin, F. \& Higgins, D. G. (1997). The CLUSTAL_X windows interface: flexible strategies for multiple sequence alignment aided by quality analysis tools. Nucleic Acids Res 25, 4876-4882.

Uchida, K. \& Aida, K. (1984). An improved method for the glycolate test for simple identification of the acyl type of bacterial cell walls. J Gen Appl Microbiol 30, 131-134.

Vobis, G. (1989). Actinoplanetes. In Bergey's Manual of Systematic Bacteriology, vol. 4, pp. 2418-2419. Edited by S. T. Williams, M. E. Sharpe \& J. G. Holt. Baltimore: Williams \& Wilkins.

Williams, S. T. \& Cross, T. (1971). Actinomycetes. Methods Microbiol 4, 295-334.

Yokota, A., Tamura, T., Hasegawa, T. \& Huang, L. H. (1993). Catenuloplanes japonicus gen. nov., sp. nov., nom. rev., a new genus of the order Actinomycetales. Int J Syst Bacteriol 43, 805-812. 